\title{
FAKTOR-FAKTOR YANG MEMPENGARUHI SELF DIRECTED LEARNING READINESS PADA MAHASISWA TAHUN PERTAMA, KEDUA DAN KETIGA DI FAKULTAS KEDOKTERAN UNIVERSITAS HASANUDDIN DALAM PBL
}

\author{
Hasan Nyambe*, Harsono**, Gandes Retno Rahayu** \\ * Jurusan Kedokteran, Fakultas Kedokteran Universitas Hasanuddin \\ ** Departemen Pendidikan Kedokteran, Fakultas Kedokteran Universitas Gadjah Mada
}

\begin{abstract}
Background: The study explores the factors that affecting the readiness to (self-directed learning readiness) in the context of PBL is still rare, especially when in fact unprepared students in the initiative and the desire for self-learning, a lack of understanding of students on independent learning and interpretation mischaracterized the self-learning (self directed learning) is still frequently encountered. This study aimed to measure simultaneously identify factors that influence student SDLR in the first, second and third at the Medical Faculty of Hasanuddin University.

Method: through two stages (sequencing), which combines two research approaches, namely qualitative as the main approach (dominant) and quantitative approaches as facilitators (less dominant). data collection with questionnaires and focus group discussions. The number of subjects quantitative 399 people (143 people from the first year, 152 the second year and 104 people from the third year), while for FGD about 18 people who set out with purposive sampling. Distributing questionnaires carried out in advance to obtain SDLR categories of high, medium and low, followed by FGD each batch by category SDLRnya. The analysis starts with the transcription process then the coding process.

Results: This study shows that the average score lowest SDLR owned by First-year students FK UNHAS while the highest SDLR owned by Second year students. Not found SDLR category lower because students have had plenty of experience of active and independent learning that develops steadily. There are several factors that affect SDLR construct the desire to learn, self-control and self-management.

Conclusion: Factors that affect SDLR the first year students, second and third in the FK Unhas divided into two, namely: (1) internal factors which consist of physical health, the availability of leisure time, hobby or avocation, self maturity, and intelligence; (2) external factors which consists of the support of family and friends, faculty facilities, problems, relationships between peers, and the influence of parents and friends
\end{abstract}

Keywords: self directed learning readiness (SDLR), PBL, independent study, factors affecting

\begin{abstract}
ABSTRAK
Latar belakang: Penelitian yang mengeksplorasi mengenai faktor-faktor yang berpengaruh terhadap kesiapan belajar mandiri (self directed learning readiness) dalam konteks PBL masih jarang dijumpai, padahal Kenyataannya ketidaksiapan mahasiswa khususnya dalam inisiatif dan keinginan untuk belajar mandiri, kurangnya pemahaman mahasiswa tentang pembelajaran mandiri serta interpretasi yang keliru mengenai belajar mandiri (self directed learning) masih sering dijumpai. Penelitian ini bertujuan untuk mengukur sekaligus mengidentifikasi faktor-faktor yang mempengaruhi SDLR pada mahasiswa tahun pertama, kedua dan ketiga di Fakultas Kedokteran Unhas.

Metode: melalui dua tahapan (sequencing), yang mengkombinasikan dua pendekatan penelitian, yaitu kualitatif sebagai pendekatan utama (dominan) dan pendekatan kuantitatif sebagai fasilitator (less dominant).
\end{abstract}

korespondensi: gagah152@gmail.com 
pengumpulan data dengan kuesioner dan FGD. Jumlah subjek kuantitatif 399 orang (143 orang dari tahun I, 152 orang tahun II dan 104 orang dari tahun III), sedangkan untuk FGD sebanyak 18 orang yang ditetapkan dengan purposive sampling. Penyebaran kuesioner dilakukan terlebih dahulu untuk mendapatkan kategori SDLR tinggi, sedang dan rendah, dilanjutkan dengan FGD tiap angkatan berdasarkan kategori SDLRnya. Analisis dimulai dengan proses transkripsi kemudian proses koding.

Hasil: Penelitian ini menunjukkan bahwa Rata-rata skor SDLR paling rendah dimiliki oleh mahasiswa tahun Pertama FK Unhas sedangkan SDLR paling tinggi dimiliki oleh mahasiswa tahun Kedua. Tidak ditemukan kategori SDLR rendah karena mahasiswa telah punya banyak pengalaman belajar aktif dan mandiri yang berkembang terus. Terdapat beberapa faktor yang mempengaruhi konstruk SDLR yaitu keinginan untuk belajar, kontrol diri dan manajemen diri.

Kesimpulan: Faktor-faktor yang mempengaruhi SDLR pada mahasiswa tahun pertama, kedua dan ketiga di FK Unhas dibagi menjadi dua yaitu: (1) faktor internal yang terdiri dari kesehatan fisik, ketersediaan waktu luang, hobi atau kegemaran, kematangan diri, dan kecerdasan; (2) faktor eksternal yang terdiri dari dukungan keluarga dan teman, fasilitas fakultas, masalah yang dihadapi, hubungan antar teman sebaya, dan pengaruh orang tua serta teman

Kata kunci: Self Directed Learning Readiness (SDLR), PBL, belajar mandiri, faktor yang berpengaruh.

\section{PENDAHULUAN}

Pergeseran paradigma pendidikan kedokteran di Indonesia dari teacher centered learning/TCL ke arah student centered learning/SCL membawa dampak terhadap metode, aktivitas dan hasil belajar di fakultas kedokteran., ${ }^{1,2}$ Salah satu metode belajar yang bersifat SCL adalah problem-based learning (PBL). PBL telah diadopsi oleh banyak fakultas kedokteran di seluruh dunia. Banyak keunggulan dalam metode pembelajaran PBL, seperti mendorong pembelajaran mahasiswa lebih aktif dan mendalam, pengembangan integrasi pengetahuan dasar, persiapan kemampuan lifelong learning, peningkatan hubungan antara mahasiswa dan staf pengajar dan peningkatan motivasi mahasiswa. ${ }^{3.8}$

Beberapa keluhan ketidaksiapan mahasiswa menghadapi lingkungan belajar yang bersifat SCL ditemukan melalui diskusi dan wawancara yang tidak terstruktur, di antaranya kurangnya inisiatif dan keinginan untuk belajar mandiri. Masalah lain adalah kurangnya pemahaman mahasiswa tentang pembelajaran mandiri serta interpretasi yang keliru mengenai belajar mandiri (self directed learning), dan tidak mempunyai tanggung jawab terhadap kegiatan belajarnya sendiri.

Dalam lingkungan belajar yang menuntut keaktifan dan kemandirian mahasiswa diperlukan pemahaman mengenai Self Directed Learning Readiness (SDLR) dan faktor yang mempengaruhinya. SDLR merupakan kesiapan atau kesediaan seseorang untuk belajar mandiri, yang terdiri dari komponen sikap, kemampuan dan karakteristik personal. ${ }^{9-11}$ Beberapa penelitian menyebutkan bahwa SDLR mahasiswa semakin meningkat tiap tahun, akan tetapi berdasarkan fakta di Fakultas Kedokteran Unhas tetap ditemukan keluhan pada mahasiswa tahun ketiga mengenai kesiapan untuk belajar mandiri yang, sehingga perlu dilihat ada tidaknya faktor yang mempengaruhi SDLR pada mahasiswa dan melihat perbedaan faktor yang kuat pada mahasiswa yang berbeda angkatan. Penelitian ini bertujuan untuk mengukur sekaligus mengidentifikasi faktorfaktor yang mempengaruhi SDLR pada mahasiswa tahun pertama, kedua dan ketiga di Fakultas Kedokteran Unhas. Diketahuinya faktor-faktor yang mempengaruhi pembelajaran dalam PBL dapat menjadi suatu pertimbangan dalam meningkatkan kualitas pembelajaran mahasiswa dan meningkatkan kualitas PBL dalam suatu institusi pendidikan umumnya, dan khususnya di FK Unhas.

\section{METODE}

Penelitian ini merupakan penelitian yang dilakukan melalui dua tahapan (sequencing), yang meng- 
kombinasikan dua pendekatan penelitian, yaitu pendekatan kuntitatif dan kualitatif. Kualitatif sebagai pendekatan utama (dominan) dan pendekatan kuantitatif sebagai fasilitator (less dominant). Subjek penelitian adalah mahasiswa Fakultas Kedokteran Universitas Hasanuddin tahun pertama, kedua dan ketiga yang berjumlah 399 orang yang terdiri dari 124 pria dan 275 wanita. Dengan rincian 143 orang dari tahun I (39 pria dan 104 wanita), 152 orang tahun II (53 pria dan 99 wanita) dan 104 orang dari tahun III (32 pria dan72 wanita). Pada penelitian ini mahasiswa yang tidak terdaftar pada semester berjalan atau yang mengambil cuti, dan mahasiswa yang tidak bersedia menjadi responden akan dimasukkan ke dalam kriteria eksklusi.

Cara pengumpulan data dalam penelitian ini melalui dua tahapan (sequencing). Tahapan pertama adalah mengukur SDLR mahasiswa tahun pertama, kedua dan ketiga di FK Unhas menggunakan skala self-directed learning readiness scale (SDLRS). Skala SDLRS yang digunakan dalam penelitian ini merupakan adaptasi dari SDLRS berbahasa inggris yang dikembangkan oleh Fisher. Skala ini terdiri dari 40 butir yang terdistribusi dalam tiga konstruk yaitu, manajemen diri, keinginan untuk belajar, dan kontrol diri., ${ }^{912-15}$ Langkah-langkah proses adaptasi skala dilakukan dengan mengikuti petunjuk adaptasi skala yang disusun oleh World Health Organization (WHO) yang terdiri dari forward translation, expert panel, back-translation, pre-testing dan final version. Validitas isi SDLRS dilakukan melalui proses pengembangan butir-butir skala melalui studi literatur, panel ahli dengan teknik Delphi dan, menggunakan faktor analisis..$^{16}$ Sebelum Analisis realibilitas skala dilakukan dengan bantuan program komputer statistical Package for the Social Sciences (SPSS) versi 15. Dari hasil komputasi yang dinyatakan dalam corrected butir total correlation, butir butir yang dipilih adalah yang mempunyai koefisien reabilitas minimal 0,268. Skala self-directed learning readiness scale yang telah diujicoba, sahih sebanyak 36 butir dan gugur sebanyak 4 butir.

Tahap kedua melalui Focus Group Discussion (FGD) bertujuan untuk mengeksplorasi mengenai faktorfaktor yang mempengaruhi self-directed learning readiness pada mahasiswa tahun pertama, kedua, dan ketiga di Fakultas Kedokteran Universitas hasanuddin. Penentuan subjek dilakukan setelah mendapatkan hasil SDLR pada tahapan pertama. Subjek ditentukan dengan sistem purpose sampling berdasarkan kategori SDLR mahasiswa. Oleh karena tidak ada mahasiswa yang berada pada kategori SDLR rendah maka pada peneltitian ini hanya dibentuk kelompok FGD (FGD tahun pertama, kedua dan ketiga) dengan keterwakilan dari masing-masing skor SDLR tinggi, dan sedang. Tiap kategori SDLR untuk tiap angkatan dipilih 3 orang, Sehingga total jumlah mahasiswa yang terlibat dalam FGD adalah 18 orang. Metode ini menggunakan pertanyaan terbuka dengan pedoman wawancara sebagai panduan.

Analisis hasil penelitian dimulai dengan analisis statistik deskriptif yang bertujuan untuk mengetahui nilai rata-rata, standar deviasi (SD), nilai minimum dan nilai maksimum variabel penelitian. Dengan uji one-way ANOVA kemudian membandingkan skor SDLR mahasiswa tahun pertama, kedua dan ketiga. Analisis berikutnya adalah analisis data kualitatif. Teknik yang digunakan adalah analisis konten (content analysis) yang meliputi proses identifikasi, pengkodean, dan kategorisasi data. Data dari hasil wawancara dibuatkan transkrip. Berdasarkan hasil wawancara dalam bentuk transkrip, akan ditemukan tema-tema yang relevan dengan pertanyaan penelitian dan dikategorisasikan berdasarkan tema yang muncul tersebut. Data kualitatif ini berfungsi untuk menguatkan data pada metode kuantitatif. ${ }^{16,17}$

Pada penelitian ini, trustworthiness diupayakan dengan melakukan triangulasi metode, member checks, penulisan deskripsi yang lengkap, dan audit trail.

\section{HASIL DAN PEMBAHASAN}

\section{Studi kuantitatif}

Hasil Penelitian kuantitatif seperti pada tabel 1 dibawah menunjukkan bahwa rata-rata skor SDLR paling rendah dimiliki oleh angkatan mahasiswa tahun I yaitu 132,52 ( $\mathrm{SD}=13,77)$ dengan range nilai 102-177 sedangkan rata-rata skor paling tinggi dimiliki oleh angkatan mahasiswa tahun II yaitu $140,22(\mathrm{SD}=15,48)$ dengan range 86-180. Begitu pula dengan rata-rata skor mahasisiwa tahun III yaitu 138,13 (SD=14,01) dengan range 95-174 lebih tinggi dari tahun I tetapi lebih rendah dari tahun II. 
Tabel 1. Deskripsi data hasil penelitian SDLR tiap angkatan

\begin{tabular}{cccccc}
$\begin{array}{c}\text { SDLR } \\
\text { mahasiswa }\end{array}$ & $\begin{array}{c}\text { Jumlah } \\
\text { subjek }\end{array}$ & $\begin{array}{c}\text { Skor } \\
\text { rata-rata }\end{array}$ & $\begin{array}{c}\text { Standar } \\
\text { deviasi }\end{array}$ & $\begin{array}{c}\text { Skor } \\
\text { terendah }\end{array}$ & $\begin{array}{c}\text { Skor } \\
\text { tertinggi }\end{array}$ \\
\hline Angkatan 2014 & 143 & 132,52 & 13,77 & 102 & 177 \\
Angkatan 2013 & 152 & 140,22 & 15,48 & 86 & 180 \\
Angkatan 2012 & 104 & 138,13 & 14,01 & 95 & 174 \\
\hline
\end{tabular}

Uji homogenitas varians dengan hasil taraf signifikansi sebesar 0,672 (probabilitas >0,05) atau ketiga varians populasi identik. Hasi Uji Anova pada ketiga kelompok menunjukkan taraf signifikansi 0,001 (probabilitas <0,05) yang menunjukkan hasil bahwa terdapat perbedaan tingkat kesiapan sebagai pembelajar mandiri antara angkatan 2014, angkatan 2013 dan angkatan 2012.
Skor SDLR dalam bentuk skala interval belum dapat dipakai untuk menginterpretasikan hasil skor. Oleh karena itu, skor skala SDLR kemudian dikategorisasikan menjadi 3 tingkatan yaitu rendah, sedang dan tinggi. Hasil perhitungannya dapat dilihat pada tabel $2 .{ }^{18}$

Tabel 2. Hasil perhitungan kategorisasi skala SDRL

\begin{tabular}{llll} 
Rumus & Hasil hitung & Batasan skor & Kategori \\
Skor $\geq(\mu+1, \sigma)$ & Skor $\geq[108+1(24)]$ & Skor $\geq 132$ & Tinggi \\
Skor $(\mu-1, \sigma) \leq$ Skor $<(\mu+1 . \sigma)$ & {$[108-1(24)] \leq$ skor $<[108+1(24)]$} & $84 \leq$ skor $<132$ & sedang \\
Skor $<(\mu-1, \sigma)$ & Skor $<[108-1(24)]$ & Skor $<84$ & Rendah \\
\hline
\end{tabular}

Setelah batasan skor untuk kategorisasi di dapat maka kelompok yang memiliki kategori SDLR tinggi pada mahasisiwa tahun I sebanyak 77 orang atau sebesar 53,8\%, kelompok yang memiliki kategori SDLR sedang sebanyak 66 orang atau sebesar 46,2\% dan kelompok yang memiliki kategori SDLR rendah tidak ada atau sebesar $0 \%$. Sedangkan untuk mahasiswa tahun II jumlah repsonden yang memiliki kategori SDLR tinggi sebanyak 119 orang (78,3\%), kelompok yang memiliki SDLR sedang sebanyak 33 orang $(21,7 \%)$ dan tidak ada responden memiliki SDLR rendah (0\%). Mahasiswa tahun III jumlah kelompok yang memiliki kategori SDLR tinggi sebanyak 71 orang atau sebesar 68\%, sedangkan kelompok yang memiliki kategori SDLR sedang sebanyak 33 orang atau sebesar $31,7 \%$ dan tidak ada responden yang memiliki kategori SDLR rendah. Untuk data lebih lanjut dapat dilihat pada tabel 3 berikut ini.

Tabel 3. Kategori skor SDLR tiap tahun masuk

\begin{tabular}{ccccc}
\multirow{2}{*}{ Angkatan } & \multicolumn{3}{c}{ Kategori SDLR } & total \\
\cline { 2 - 4 } & Tinggi $(\%)$ & Sedang $(\%)$ & Rendah(\%) & \\
\hline 2014 & $77(53,8)$ & $66(46,2)$ & $0(0)$ & 143 \\
2013 & $119(78,3)$ & $33(21,7)$ & $0(0)$ & 152 \\
2012 & $71(68,3)$ & $33(31,7)$ & $0(0)$ & 104 \\
\hline
\end{tabular}


Fisher et.al (2001) mengembangkan skala SDLR terdiri dari tiga konstruk atau aspek yaitu, keinginan untuk belajar (desire for learning). Manajemen diri (self management), dan kontrol diri (self control). Dari tabel 4 di bawah dapat dilihat bahwa nilai rata-rata konstruk keinginan untuk belajar untuk angkatan 2012 lebih tinggi dari angkatan 2013 dan angkatan 2014. untuk nilai rata-rata konstruk manajemen diri mahasiswa angkatan 2012 lebih tinggi dari pada angkatan 2014 tapi lebih rendah dari angkatan 2013, begitu pula halnya dengan nilai rata-rata konstruk kontrol diri angkatan 2012 lebih tinggi dari pada angkatan 2014, tetapi lebih rendah dari angkatan 2013. Hal ini mungkin disebabkan oleh terdapatnya beberapa faktor yang turut berpengaruh dalam penentuan ketiga konstruk SDLR.

Tabel 4. Rata-rata skor konstruk skala SDLR

\section{Kelompok SDLR}

Rata-rata skor konstruk skala SDLR

Keinginan untuk belajar Manajemen diri $\quad$ Kontrol diri

Angkatan 2014

$\begin{array}{lccr}\text { Tinggi } & 40,88 & 48,45 & 52,95 \\ \text { sedang } & 36,45 & 41,23 & 45,32 \\ \text { Angkatan 2013 } & & & \\ \text { Tinggi } & 41,23 & 51,53 & 53,48 \\ \text { sedang } & 34,09 & 40,61 & 43,85 \\ \text { Angkatan 2012 } & & \\ \text { Tinggi } & 41,77 & 50,85 & 52,08 \\ \text { sedang } & 36,52 & 43,03 & 44,09\end{array}$

Hasil penelitian memperlihatkan bahwa mahasiswa tahun kedua yang berada pada kategori SDLR tinggi lebih besar persentasenya dari pada mahasiswa tahun pertama, tapi tidak demikian halnya dengan mahasisiwa tahun ketiga yang mempunyai kategori SDLR tinggi lebih kecil persentasenya daripada mahasiswa tahun kedua. Dari hasil wawancara yang terarah ditemukan bahwa mahasiswa tahun pertama FK unhas telah pernah mengalami lingkungan belajar yang bersifat aktif serta mandiri sewaktu mereka belajar di SMA ataupun karena pengalaman belajar mandiri di beberapa blok pada semester sebelumnya. Bentuk belajar mandiri yang dijalani seperti pemberian tugas untuk didiskusikan, program penelitian bersama tenaga pengajar, tugas perorangan. Pengalaman ini telah menambah tingkat kesiapan mereka untuk belajar mandiri. Faktor tersebut diatas yang menyebabkan tidak ditemukannya mahasiswa yang berada dalam kategori SDLR rendah baik tahun pertama, kedua maupun ketiga.

Dari hasil wawancara juga dapat diidentifikikasi beberapa faktor yang mempengaruhi kesiapan belajar mandiri mahasiswa FK Unhas, khususnya pada mahasiswa tahun ketiga sehingga memiliki SDLR yang lebih rendah dari tahun sebelumnya, yaitu:

1. Ketersediaan waktu luang bagi mahasiswa karena ikut aktif dalam organisasi kemahasiswaan dan ekstrakurikuler yang banyak menyita waktu pribadi untuk belajar aktif dan mandiri.

2. Kurikulum yang berlaku dalam lingkungan FK Unhas serta pelaksanaannya, termasuk didalamnya adalah metode pengajaran yang diterapkan oleh tenaga pengajar yang belum sepenuhnya mendukung kesiapan belajar mandiri mahasiswa. 


\section{Studi kualitatif}

Untuk mengetahui mengapa tidak ditemukannya mahasiswa FK Unhas yang berada dalam tingkat SDL rendah serta mengapa mahasiswa tahun ketiga tingkat SDLnya lebih rendah, maka dilakukan wawancara yang terarah untuk mencari apakah ada faktor yang mempengaruhi mahasiswa tahun pertama, kedua, dan ketiga FK unhas dalam SDL.

Dari hasil wawancara yang terarah ditemukan bahwa mahasiswa tahun pertama FK unhas telah pernah mengalami lingkungan belajar yang bersifat aktif serta mandiri sewaktu mereka belajar di SMA atau yang sederajat walaupun tingkat kemandirian yang dibutuhkan tidak sebesar di FK, seperti yang dituturkan oleh informan:

"Dari kelas satu kami sudah KBK, semua cara belajar..anu..sudah pakai powerpoint, guru hanya memperlihatkan tema besarnya saja, guru sering kasi diskusi, meskipun cuma pake satu guru untuk satu kelas yang jumlah muridnya 40 ya. Gurunya lalu kasi kita tugas, kayak tugas biologi dan fisika, disuruh kembangkan dari tema yang dikasih, lalu nanti didiskusikan." (4106014)

Hal yang senada di ungkapkan oleh mahasiswa tahun kedua, disamping mereka sudah mendapatkan pengalaman belajar mandiri sejak SMA, mereka juga terlatih sejak semester awal di Fk Unhas untuk belajar secara aktif dan mandiri, dimana mereka yang lebih banyak dituntut untuk belajar sendiri sementara tenaga pengajar hanya berfungsi sebagai fasilitator. Seperti yang dituturkan oleh informan:

"kita kan sudah semester tiga dok, jadi pengalaman belajar PBL di beberapa blok kemarin menambah tingkat belajar mandiri. Apalagi kalo habis kuliah yang susah deh seperti anatomi...maaf dok ya...apa boleh buat harus belajar sendiri sampai kira-kira bisa." (14406013)

Lain halnya dengan mahasiswa tahun ketiga yang memilki SDLR tinggi, telah banyak faktor yang mempengaruhi selama kurun waktu tertentu mereka di lingkungan FK Unhas antar lain kurangnya waktu luang, terlalu banyak mengikuti kegiatan organisasi intrafakultas maupun kurikulum yang berlaku serta pelaksanaannya, seperti yang dituturkan oleh informan yang memiliki SDLRtinggi :

"susah juga sih dok terus-terusan diskusi, masalahnya kami banyak yang jadi pengurus organisasi jadi susah bagi waktunya untuk belajar sendiri...ya lebih banyak urusin TBM saya, nginap dikampus jadi sedikit waktu belajarnya." (29806012)

\section{Keinginan untuk belajar}

Dari hasil penelitian kualitatif ditemukan bahwa mahasiswa yang memiliki SDLR tinggi merasa bahwa belajar itu menyenangkan, dan memandang belajar itu sebagai hobi, apalagi jika materi pembelajaran tergolong sulit maka mereka tertantang untuk bisa menguasainya, seperti yang dituturkan oleh mahasiswa tahun kedua yang memiliki SDLR tinggi:

“...saya berusaha supaya belajar itu menjadi kegiatan menyenangkan, seperti hobilah gitu dok, ...cuman meskipun masih kalah dengan besarnya hobi saya seperti main game... Main game bisa sampe berjam-jam, tapi belajar ..ya..paling satu jam sudah loyo." (19306013)

Rasa ingin tahu yang kuat dapat memotivasi untuk belajar yang sangat besar, seperti yang dituturkan oleh mahasiswa tahun ketiga yang memiliki SDLR tinggi:

"betul dok kata teman saya, kalo ada materi yang susah dipahami, dicari dimana-mana bahannya, internet lah, nanya senior co-ass, kalo belum puas susah tidur rasanya. He.. he..apalagi kalo ada pertanyaan dosen PBL yang tidak bisa dijawab." (29806012)

Mahasiswa yang memiliki SDLR sedang merasa belajar itu sebagai beban sehingga sering mengeluh bila belajar, seperti yang dituturkan oleh mahasiswa tahun kedua yang memiliki SDLR sedang : 
"jadikan hobi? susah dok, masih menyenangkan bikin yang lain. Belajar kalo ada mau ujian saja." (21907013)

Hal yang sama dituturkan oleh mahasiswa tahun kedua yang memiliki SDLR sedang:

"pernah sih coba jadi hobi, tapi malah memberatkan, saya belajar kalo terpaksa saja. Kayak mau kuis praktikum anatomi misalnya. Kan malu sama pacar tidak lulus kalo tidak lulus." (26007013)

Keinginan untuk belajar mahasiswa yang memiliki SDLR sedang berasal dari motivasi ekstrinsik seperti ancaman DO (drop out) apabila tidak mencapai batas minimal prestasi belajar yang telah disyaratkan, seperti yang dituturkan oleh mahasiswa tahun pertama yang memiliki SDLR sedang:

"yang penting kan bebas DO dok, saya sih orangnya santai aja, nikamti hidup. Jadi belajar seperlunya saja supaya bebas ancaman DO." (9707014)

Faktor-faktor yang mempengaruhi keinginan untuk belajar diperoleh melalui penuturan beberapa informan baik dari tahun pertama, kedua maupun ketiga. Beberapa faktor yang teridentifikasi antara lain kondisi kesehatan secara fisik yang dimiliki, Seperti yang dituturkan oleh mahasiswa tahun pertama yang memiliki SDLR tinggi:

"pernah mau memaksakan diri belajar dok, tapi...saya kan lagi tidak enak badan waktu itu, padahal belajar itu kan bagus.tapi.. yaa...mau diapa lagi terpaksa tidur saja dulu." (9406014)

Faktor lain yang turut mempengaruhi adalah masalah yang dihadapi serta penanganannya, dan hobi atau kegemaran. Seperti yang dituturkan oleh mahasiswa tahun ketiga yang memiliki SDLR sedang:

"sebenarnya belajar itu wajib, apalagi kalo kita di kedok. Tapi bagaimana dengan saya hobi bola saya susah dikalahkan sama belajar,..belum lagi kalo misalnya ada masalah, kayak baru putus, atau tunggakan kos belum dibayar, kan pusing tuh....jadi belajarnya ditunda dulu sampai betul-betul beres masalahnya." (34907012)

Kecerdasan yang dimiliki, dukungan keluarga, teman-teman yang dipunyai, dan perlengkapan atau fasilitas yang dimiliki fakultas juga teridentifikasi sebagai faktor yang turut mempengaruhi keinginan belajar mahasiswa tahun pertama, kedua dan ketiga, seperti yang dituturkan oleh mahasiswa tahun pertama yang memiliki SDLR tinggi:

"pertama kali saya di kedokteran, agak susah untuk bisa senang belajar, masalahnya pace dan mace tidak mendukung masuk kedokteran, maunya farmasi, untung temantemanku selalu support dan mengajak belajar bersama." (0206014)

"pernah dua hari internet mati dikampus, bagaimana caranya mau senang belajar kalo begini..padahal kan mau cari bahan." (19306013)

Dorongan untuk belajar timbul dari motivasi belajar yang merupakan daya penggerak atau pendorong untuk terlibat dalam proses belajar. Motivasi dapat diklasifikasikan menjadi dua: (1) motivasi intrinsik, yaitu motivasi yang timbul dari dalam diri pribadi seseorang itu sendiri, seperti sistem nilai yang dianut, harapan, minat, cita-cita, dan aspek lain yang secara internal melekat pada seseorang; dan (2) motivasi ekstrinsik, yaitu motivasi yang muncul dari luar diri pribadi seseorang, seperti dorongan orang tua, guru, teman, kondisi lingkungan sekolah, adanya ganjaran barupa hadiah (reward) dan perasaaan takut oleh hukuman (punishment). 19-21 Dari hasil penelitian kualitatif diemukan bahwa mahasiswa yang memiliki SDLR tinggi memiliki keinginan untuk belajar yang timbul dari motivasi intrinsik seperti menganggap belajar sebagai hobi dan menyenangkan, rasa ingin tahu yang kuat dan harapan untuk menjadi 
dokter yang benar-benar kompeten. Mahasiswa yang memiliki motivasi intrinsik ini akan belajar karena dorongan dari dalam dirinya sendiri sehingga keterlibatannya dalam proses belajar dapat bertahan lama. Dalam lingkungan belajar yang berpusat pada mahasiswa, motivasi intrinsik sangat berperan dalam mendorong mahasiswa untuk belajar. sedangkan mahasiswa yang memiliki SDLR sedang memiliki keinginan untuk belajar yang timbul dari motivasi ekstrinsik seperti takut di DO dan memandang belajar itu sebagai beban yang terpaksa dilaksanakan guna menghindari hukuman.

Faktor-faktor yang mempengaruhi keinginan untuk belajar dari hasil wawancara diperoleh antara lain kondisi kesehatan secara fisik yang dimiliki oleh mahasiswa, Masalah yang dihadapi serta penanganannya, Pengaruh hobi atau kegemaran, kecerdasan yang dimiliki oleh mahasiswa, dukungan dari keluarga, temanteman yang dipunyai, dan perlengkapan atau fasilitas yang dimiliki fakultas kedokteran Unhas.

\section{Manajemen diri}

Manajemen diri berhubungan erat dengan manajemen waktu. Mahasiswa yang memiliki SDLR tinggi mampu mengatur waktunya dengan baik, seperti yang dituturkan oleh mahasiswa tahun ketiga yang memiliki SDLR tinggi:

"waktu belajar saya sudah di tulis-tulis dikertas lalu tempel di dinding kamar, jam berapa belajar farmako, atau lainnya. Jadi pulang dari kampus biasanya sampe dirumah jam habis magrib, setelah shalat, makan malam, belajarlah sampai jam 10.30." (33406012)

Hal serupa dituturkan mahasiswa tahun kedua yang memiliki SDLR sedang:

"waktu..ee...meskipunsayasusah meluangkan waktu, tapi kalo serius ingin belajar, mata kuliah ini harus selesai. Makanya dibagi waktunya, pulang kuliah sore mulai, habis makan malam lanjut belajar, kalo sudah diatas jam sebelas mengantuk...tidur." (14807013)

Sedangkan mahasiswa yang memiliki SDLR sedang memiliki kesulitan dalam mengatur waktunya dengan baik. Ia merasa dikejar-kejar oleh waktu dan waktu terasa sangat singkat, seperti yang dituturkan oleh mahasiswa tahun ketiga yang memiliki SDLR sedang:

"belajarnya tidak tentu juga dok..kalo mau belajar, ya belajar. masalahnya kalo mau mengatur waktunya susah, pulang dari kegiatan kemahasiswaan sudah malam, eh belum mandi, makan, mau belajar sudah larut malam, ya tidur de." (31507012)

Mahasiswa yang memiliki SDLR tinggi mempunyai prioritas dalam belajar, serta tidak mau menundanunda apa yang telah direncanakannya, seperti yang dituturkan oleh mahasiswa tahun ketiga yang memiliki SDLR tinggi:

"Meskipun aktif organisasi bagi saya belajar lebih penting dok, kalo ada pleno besoknya, urusan BEM bisa ditunda, mending pulang kerumah atau kumpulsama teman membahas materi yang akan diplenokan...jadi bagi saya prioritas ya..belajar." (29806012)

Sedangkan mahasiswa yang memiliki SDLR sedang memiliki kesulitan dalam manajemen waktu. Ia kurang dapat melaksanakan apa yang telah direncanakannya, seperti yang dituturkan oleh mahasiswa tahun kedua yang memiliki SDLR sedang:

"sudah sering sekali dok saya niatkan nanti belajar jam 7 sampai jam setengah sepuluh, tapi eh.. ada acara bola di TV. Lupa belajarnya, habis nonton sudah mengantuk, pasang weker jam 3, dengar tapi di matikan lagi." (26007013)

Beberapa faktor yang teridentifikasi mempengaruhi manajemen diri antara lain kondisi kesehatan secara fisik dan minat yang dimiliki, seperti yang 
dituturkan oleh mahasiswa tahun pertama yang memiliki SDLR sedang:

"saya selalu tepat waktu belajar, cuman... sudah dua hari saya tidak ikut jadwal, bahkan kemarin telat datang kuliah...sakit dok, kayaknya anu...tipesku kambuh." (0107014)

Faktor lain yang teridentifikasi adalah banyak sedikitnya waktu luang, dan hubungan antar teman sebaya, seperti yang dituturkan oleh mahasiswa tahun ketiga yang memiliki SDLR tinggi:

"iya...karena banyak kegiatan ekskul, jadi kadang-kadang susah bagi waktunya. Itu juga kalo aktifki banyak teman, kdangkadang dipanggil keluar, tidak jadimi lagi belajar" (29607012)

Berdasarkan Hasil penelitian kuantitatif dijelaskan bahwa kemampuan manajemen diri mahasiswa yang memiliki SDLR tinggi lebih baik dibandingkan mahasiswa yang memiliki SDLR sedang. Mahasiswa yang memiliki SDLR tinggi memiliki manajemen waktu dan disiplin diri yang lebih baik dibandingkan mahasiswa yang memiliki SDLR sedang. Mahasiswa yang memiliki SDLR tinggi mampu mengatur waktunya dengan baik dan selalu ingin disiplin dalam belajar, sedangkan mahasiswa yang memiliki SDLR sedang memiliki kesulitan dalam mengatur waktunya dengan baik dan merasa dikejar-kejar oleh waktu serta kurang disiplin dalam melaksanakan apa yang telah ditetapkannya.

Faktor-faktor yang mempengaruhi manajemen diri pada mahasiswa tahun pertama, kedua dan ketiga FK Unhas dari hasil wawancara, adalah: kondisi kesehatan secara fisik yang dimiliki oleh mahasiswa, Ketersediaan waktu luang bagi mahasiswa karena ikut aktif dalam organisasi kemahasiswaan dan ekstrakurikuler yang banyak menyita waktu pribadi untuk belajar aktif dan mandiri, dan Hubungan antar teman sebaya.

\section{Kontrol diri}

Dari hasil wawancara ditemukan bahwa mahasiswa yang memiliki SDLR sedang merasa pengaruh teman-temannya dalam proses belajar membuat ia susah untuk mengontrol minat, sikap dan usahanya terhadap proses belajar, seperti yang dituturkan oleh mahasiswa tahun ketiga yang memiliki SDLR sedang:

"wah susah dok, nanti dibilang tidak gaul. apalagi saya dari daerah, Jadi kalo dipanggil nonton, meskipun mau belajar ya...ikutmi." (31507012)

Demikian juga halnya dengan pengaruh orang tua dalam proses belajar, sehingga ia susah untuk mengontrol minatnya untuk belajar, seperti yang dituturkan oleh mahasiswa tahun pertama yang memiliki SDLR sedang:

"soalnya susah kalo bapak, kan bapak dokter juga, bilangnya belajar bab II saja dulu lebih penting, padahal saya maunya bab III. ikut saja bapak dulu, tapi bab III kan juga dasar."

Sedangkan mahasiswa yang memiliki SDLR tinggi merasa bahwa belajar itu karena ada kesadaran dari dalam diri sendiri sehingga dapat bertanggung jawab terhadap dirinya dan mengontrol proses belajarnya dengan baik, seperti yang dituturkan oleh mahasiswa tahun kedua yang memiliki SDLR tinggi:

\section{"kalo belajar harusnya dari kita sendiri, bukan disuruh-suruh, ya.. kesadaran sendiri lah intinya." (19306013)}

Mahasiswa yang mandiri harus mampu untuk mengontrol minat, sikap dan usahanya terhadap proses belajar tanpa dipengaruhi oleh dosen, teman atau orang tua. mahasiswa yang memiliki SDLR tinggi memiliki kemampuan kontrol diri yang lebih baik dibandingkan mahasisiwa yang memiliki SDLR sedang. Dari Hasil penelitian kualitatif diatas juga dapat diidentifikasi bahwa terdapat faktor yang turut mempengaruhi mahasiswa dalam mengontrol minatnya untuk belajar yaitu, pengaruh teman sebaya, dan pengaruh orang tua. 


\section{KESIMPULAN}

Rata-rata skor SDLR paling rendah dimiliki oleh mahasiswa tahun Pertama Fakultas Kedokteran Unhas sedangkan rata-rata skor SDLR paling tinggi dimiliki oleh mahasiswa tahun Kedua, sedangkan tahun Ketiga lebih rendah dari tahun kedua.

Faktor-faktor yang mempengaruhi Self Directed Learning Readiness (SDLR) pada mahasiswa tahun pertama, kedua dan ketiga di Fakultas Kedokteran Unhas dibagi menjadi dua yaitu: (1) faktor internal yang terdiri dari kesehatan fisik, ketersediaan waktu luang, hobi atau kegemaran, kematangan diri, dan kecerdasan; (2) faktor eksternal yang terdiri dari dukungan keluarga dan teman, fasilitas fakultas, masalah yang dihadapi, hubungan antar teman sebaya, dan pengaruh orang tua serta teman

\section{SARAN}

Hasil penelitian ini memiliki kontribusi penting dalam evaluasi pelaksanaan $\mathrm{KBK}$ di FK Unhas yakni perlu adanya peninjauan dalam peningkatan kualitas pembelajaran sesuai dengan strategi student centered seperti pemberian kuliah interaktif, kualitas skenario dan pelaksanaan tutorial/diskusi kelompok, serta penataan jadwal belajar mandiri, terutama pada tahap pendidikan system based/blok sistem.

Mahasiswa hendaknya lebih menempatkan prioritas pada kegiatan akademik dibandingkan kegitan ekstrakurikuler, dengan cara mengurangi waktu dalam kegiatan organisasi dan meluangkan waktu yang lebih untuk pembelajaran yang aktif dan mandiri.

\section{DAFTAR PUSTAKA}

1. Boud D, Feletti G. What is problem-based learning?. In D. Boud \& G. Feletti (Eds.), The challenge of problem-based learning. Ed. $2^{\text {nd. }}$. London: Kogan Page; 1997, pp 1-14.

2. Donnelly R. Fitzmaurice M. Designing Modules for Learning. In S. Moore, G. O’Neill, and B. McMullin (Eds.), Emerging Issues in the Practice of University Learning and Teaching. Dublin: AISHE; 2005, pp 99-110.

3. Dolmans D, Wolfhagen I, Vleuten C, Wijnen W. Solving problems with group work in problem-based learning: hold on to philosophy. Medical Education, 2001; 39:732-41.

4. Harsono. Pengantar Problem Based Learning. Yogyakarta: Medika Fakultas Kedokteran UGM; 2003.

5. Wood DF. ABC of learning and teaching in medicine: problem-based learning. BMJ, 2003;326:30-2.

6. Albanese MA, Mitchell S. Problem-based Learn-ing: a review of literature on its outcomes and implementation issues. Academic medicine, 1993; 68(1):52-81.

7. Baptiste ES. Problem-based learning: A self directed journey. Ontario: McMaster University; 2003.

8. Caplow JAH, Donaldson JF, Kardash CA, Hosokawa M. Learning in a problem-based medical curriculum: students' conceptions. Medical Education, 1997; 31: 440-7.

9. Fisher MJ, King J, Tague G. Development of self directed learning readiness scale for nursing education. Nurse Education Today, 2001;21:516-25.

10. Fisher MJ, King J. The self-directed learning readiness scale for nursing education revisited: A confirmatory factor analysis. Nurse Education Today, 2010;30:44-8.

11. Wiley K. Effects of a self-directed learning project and preference for structure on self-directed learning readines. Nursing Research, 1983;32(3):181-5.

12. Guglielmino L. Development of self-directed learning readiness scale. [dissertation]. University of Georgia; 1977.

13. Guglielmino LM, Guglielmino PJ. Expanding your readiness for self directed learning. Don Mills, Ontario: Organization Design and Development Inc; 1991.

14. Knowles M. Self-directed learning: A guide for learners and teachers. New York: Association Press; 1975, pp 264-71.

15. Knowles MS. Self-directed learning: A guide for learners and teachers. Chicago: Follett Publishing Company; 1980. 
16. Creswell JW. Research Design: Qualitative \& Quantitative Approaches. USA: Sage Publications; 1994.

17. Dahlan S. Statistik Untuk Kedokteran dan Kesehatan. Jakarta: Salemba Medika; 2001.

18. Azwar S. Pengantar Psikologi Intelegen-si. Yogyakarta: Pustaka Pelajar; 1996.

19. Dalyono. Psikologi Pendidikan. Jakarta: Rineka Cipta; 2007.
20. Merriam SB. Andragogy and self Directed Learning: Pillars of adult Learning Theory. New Directions Adult and continuing Education, 2001;98:3-14.

21. Miflin BM, Campbell CB, Price DA. A conceptual framework to guide the development of self-directed, lifelong learning in problem-based medical curricula. Teaching Methods, 2000;34:299-306. 